\title{
Automatic Control System for Hybrid Electrical Energy Supply Based on Internet of Things
}

\author{
M. Edwin Syah Effendy ${ }^{1}$, RD. Kusumanto ${ }^{2}$, Carlos RS ${ }^{2}$ \\ ${ }^{1}$ Renewable Energy Department, Politeknik Negeri Sriwijaya, Jl. Srijaya Negara, \\ Palembang, 30139, Indonesia \\ ${ }^{2}$ Electrical Engineering Department, Politeknik Negeri Sriwijaya, Jl. Srijaya Negara, \\ Palembang, 30139 Indonesia
}

\begin{tabular}{l} 
Article Info \\
\hline Article history: \\
Received July 11, 2021 \\
Revised August 10, 2021 \\
Accepted August 20, 2021 \\
\hline
\end{tabular}

\section{Keywords:}

Energy

Hybrid

IOT

Renewable generator

ATS

ESP32

\begin{abstract}
The utilization of renewable energy is slowly starting to become one thing that to be interesting inside the development of science technology. The utilization of renewable energy is from at least two renewable energy (Solar Power Plants and Wind Power Plants), State Electricity Enterprise (PLN), and Generator Sources. This device could be operated automatically and integrated on the internet, which has a monitoring system such as voltage, inside which will be used to control everything inside that system. This device is designed to be operated in a combinational manner. This means to be operated based on the voltage value which qualified to activate the load. The utilization of the $3.3 \mathrm{~V}$ microcontroller is able to design an efficient and low cost board. Besides that, the device also uses the PLN and Generator set sources as the power backup when the main power runs out. Base on the research noted, this device will distribute the electric source to the houses, which means beneficial for the local society. This device might be applied automatically to four different sources with $\mathrm{C}++$ Programming language to set the point value.
\end{abstract}

This is an open access article under the CC BY-SA license.

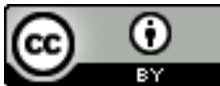

\section{Corresponding Author:}

RD. Kusumanto

Electrical Engineering Department

Politeknik Negeri Sriwijaya

Email: rd.kusumanto@polsri.ac.id

\section{INTRODUCTION}

Electrical energy is one of the vital aspect of daily human life. The continued increase in power generator capacity until 2018 reached $64.5 \mathrm{GW}$ or increased 3\% compared to 2017 capacity. 2018 mostly came from fossil energy plants, especially coal (50\%), followed by natural gas $(29 \%)$, fuel (7\%), and renewable energy (14\%). Power generator production reached $283.8 \mathrm{TWh}$, mainly from coal-fired power plants by $56.4 \%$, gas-fired power plants by $20.2 \%$, and fuel only $6.3 \%$, while $17.1 \%$ came from NRE (New Renewable Energy). The data was obtained by the general secretariat of the national energy council [1].

Along with technological advances in electricity, the continuity of the supply of electrical power is very much needed in this modern era. The main power supply from PLN (State Electricity Company) does not always exist. One day there will be blackouts caused by disturbances in the generation system, transmission system, and distribution system. Power outages can result in disruption of service continuity, especially in service activities in the trade, hotel, banking, hospital, educational centers, and industrial sectors in carrying out their production and even reaching residential homes. Easily independently without the need 
for large generators and routine maintenance is solar energy in the form of Solar Power Plants (PLTS), Wind Power Plants (PLTB), and Generators [2].

A solar cell is a component made of semiconductors that is able to convert sunlight energy into electrical energy directly using the photovoltaic (PV) principle. Solar cells are now widely used, ranging from small scales such as residential homes to large scales such as solar power plants. The advantage of using solar cells is that they can help reduce electricity costs and are environmentally friendly because they do not produce emissions and pollution [3-4]. At this time, a photovoltaic system can only be controlled and monitored for performance directly in the field where solar power is mostly installed on a rooftop mounted and installed in open areas exposed to direct sunlight, which makes observing the performance of PLTS a bit complicated, time-consuming and extensive monitoring costs [5].

Solar energy utilization to meet overall electricity needs is less effective because the sun has a limited irradiation time and the average effective irradiation time is only 8 hours. The electrical energy produced is not sufficient for electric power needs, so this system is considered to have no continuity. From this problem, it is necessary to apply smart grid hybrid system technology. A smart grid hybrid system is an electricity network that combines several types of generators integrated through a microcontroller that can be connected to the internet network via IoT or to provide electricity supply efficiently, sustainably, economically, and safely. The smart grid hybrid system here combines PLTS, PLTB, and generators [6]

Based on previous research, this research is interested in designing to combine the two references into an integrated system that can be monitored in real-time. This study aims to find the Automatic Control System for Hybrid Electrical Energy Supply based on the Internet of Things. This research focused on tools that are able to work automatically to provide supplies under certain conditions. When renewable energy is interrupted or voltage drops, the system will look for backup sources of electrical energy such as electricity from PLN and generators.

\section{RESEARCH METHOD}

\subsection{Block Diagram}

A Block diagram is an important part of designing a system. The workings of the whole system to be made can be seen in Fig. 1 so that the entire block diagram will produce a system that can be enabled or can work.

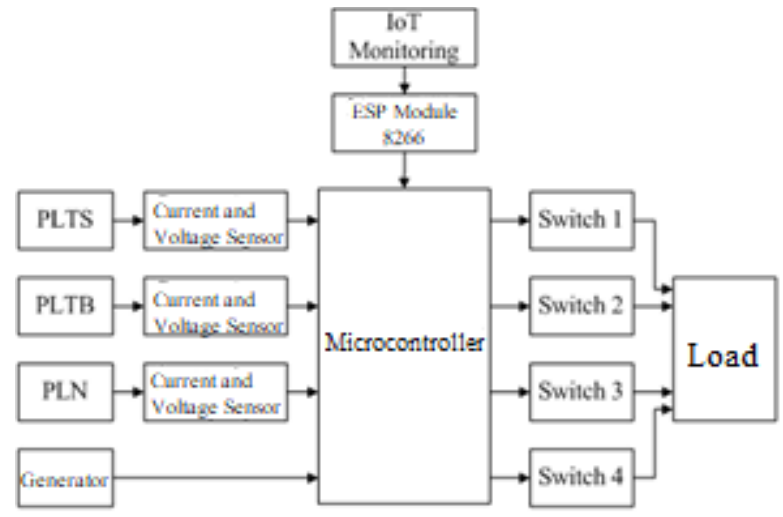

Figure 1 Block Diagram

The solar panel studied has a capacity of $100 \mathrm{WP}$, the output of the solar panel is connected to a voltage sensor as a voltage reader so that Arduino can process it via the analog IO Port, Arduino functions to process input data, send data to a data logger, Datalogger module functions to store data, modules ESP 32 as a connecting medium from users to Arduino devices via the internet network, for reading devices, besides being able to be read directly through PC devices, the design of the tool can monitor the On or Off switch output from one of the alternative electrical energy supplies of PLTS, PLTB, PLN and Generators in the form of measurement values of current, voltage and power generated through remote communication devices so that they can be monitored using mobile phones anywhere.

\subsection{Structural Design}

This circuit is divided into several parts, namely four input sources consisting of PLN, PLTS, PLTB, and Generators. This study will compare the output voltages of PLTS, PLTB, PLN, and Generators to activate the controller for selecting the energy source, which will be forwarded to the output connected to the load. AC power source from the grid and backup power source from generator set. Suppose one solar panel or wind turbine power source has more than $11 \mathrm{~V} \mathrm{DC}$ voltage to turn on the load. In that case, the system will prioritize using the output from that power source by flowing it into the battery and converting the DC power 
source to AC. However, if the two sources of power from both solar panels and wind turbines do not have enough voltage, which is more than $11 \mathrm{VDC}$, then the system will use AC power sources either from PLN or a generator set. Fig. 2 illustrates the line diagram of this research.

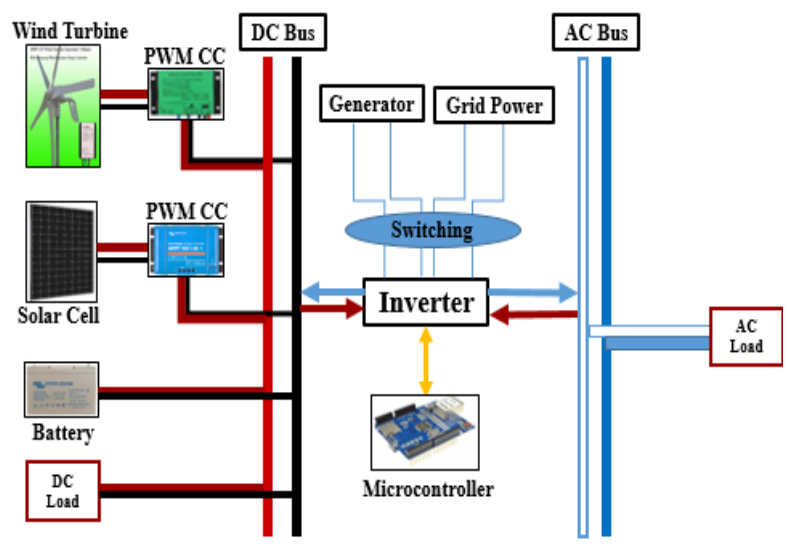

Figure 2 Diagram Line Job Research System

The wind turbine and solar cell will go through the PWM charge controller to regulate overcharging (excess charging when the battery is fully charged). Using DC power sources from renewable energy, the battery is in condition and discharge simultaneously. When the DC power source, both from solar panels and wind turbines, is less than $11 \mathrm{VDC}$, the input power source selected is AC power either from PLN or the generator set. The inverter will use this $\mathrm{AC}$ voltage and current to be forwarded to the output power while charging the battery, so when the AC power source enters the system, the battery is in charging condition and if the AC, PLN, and generator sets are not used, the battery will take transfer input resources.

\subsection{Tools Design}

Design the tool as best as possible with an estimate of the size of the tool in the form of an appropriate length, width, and height so as not to interfere with how the tool works. The components that will be used to switch on and off controlling systems on the Internet of Things-Based Automatic Control System for Hybrid Electrical Energy Supply will be selected. At this stage, references from existing research journals and other instructions can help know the specifications of these components. Select the components that will be used for the manufacture of switching on and off control systems on the Internet of Things-Based Internet of Things-Based Automatic Control System for Electricity Supply. At this stage, references from existing research journals and other instructions can help know the specifications of these components. According to the structural design, build the basic framework of the tool, such as racks to support and place the solar panels. The components and electronic devices prepared previously assembled and carried out the finishing stage, namely tidying up the tool's appearance.

2.4. Electronic Design

The initial design aims to test the tool on the project board. This process is a form of design that can change and is flexible because the components have not been permanent on the PCB board. Figure 3 showed the Display With Controller Configuration with description, which is SCL Pin on I2C module is connected to 36 controller pins, SDA Pin on I2C module is connected to 33 controller pin, VCC Pin on I2C module is connected to $5 \mathrm{~V}$ pin, and GND pin on $\mathrm{I} 2 \mathrm{C}$ module is connected to ground. 


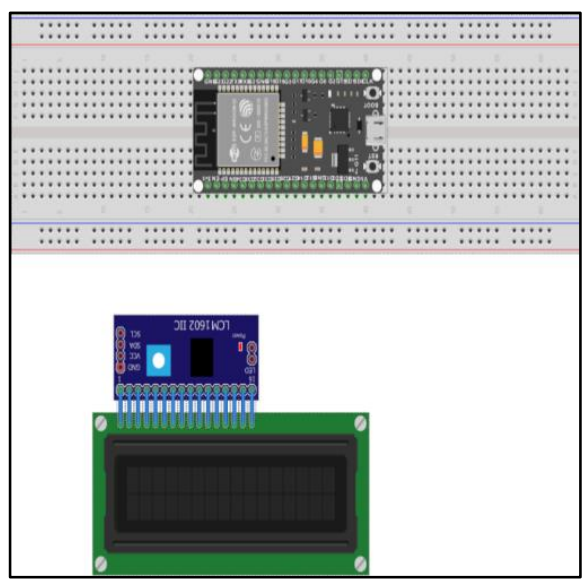

Figure 3 Display With Controller Configuration

Figure 4 illustrates the Relay With Controller Configuration of pins on the LED anode (Relay) are connected to pins 27,28,29, and 30 on the controller, and Pins on the LED cathode are connected to Ground Pin.

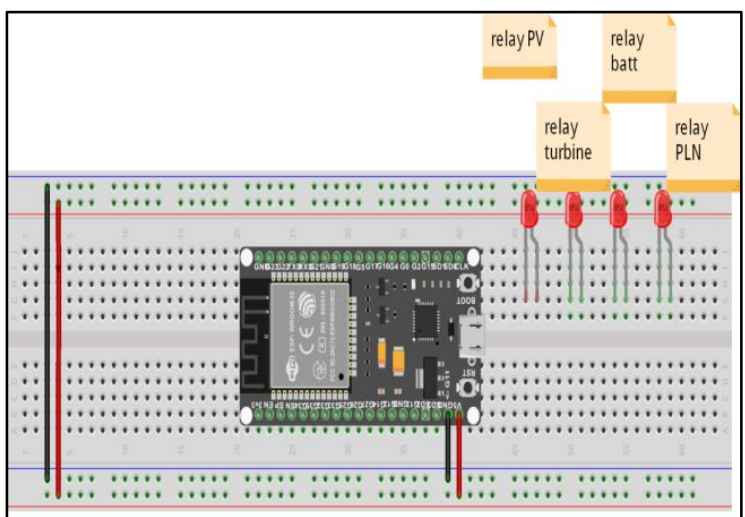

Figure 4 Relay with Controller Configuration

Figure 5 presents the voltage sensor with the configuration of the pin at the input of the input voltage source is connected to the $10 \mathrm{k}$ Ohm resistor pin, the pin on the voltage input ground is connected to the ground on the $1 \mathrm{~K} 5 \mathrm{Ohm}$ resistor, and the output signal of each sensor is between the $10 \mathrm{~K}$ and $1 \mathrm{~K} 5$ Ohm resistors connected to pins 34,35 , and 36 , respectively, on the controller.

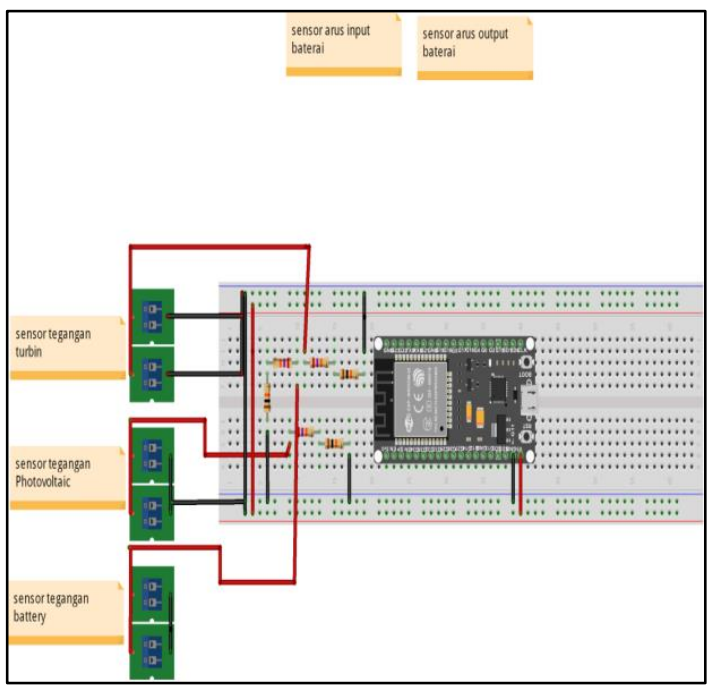

Figure 5 Voltage Sensor with Controller Configuration 


\subsection{Circuit Design}

This design aims to shorten the connected cables to be less and more efficient. Another purpose of this design is to protect the circuit from short circuits and make the integrated circuit board look proper. The PCB (printed circuit board) is a double layer type that can connect the upper and lower layers in this project. Below is a circuit design for the Internet of Things Based Hybrid Energy Control System.

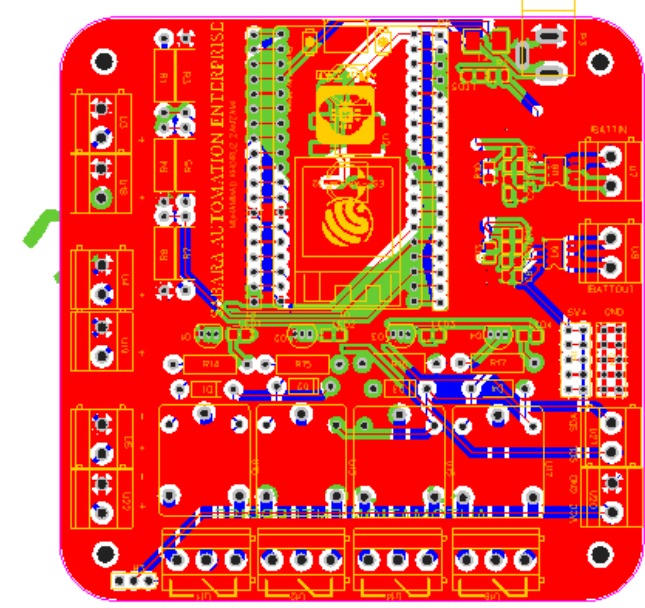

Figure 6 Outlook of Assembled Layer

Figure 6 is a circuit design that is seen as a whole, both up and down. The image above shows the top side in red and the bottom side in blue. This design uses special software to connect between components. The outlook of the top and bottom layers of the board is shown in Fig. 7.
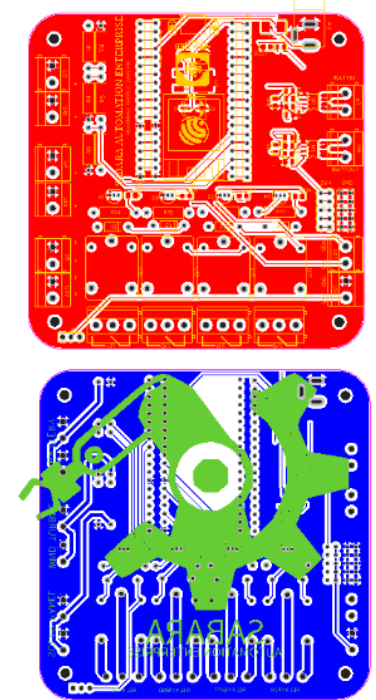

Figure 7 Outlook of Upper and Lower Layer

\subsection{Research Design}

The type, the number of solar panels and wind turbines used are determined from the type and size of the output power of the two Renewable Energy Standards (RES) on the market in accordance with considering the peak and minimum load times and the length of battery life as long as there is no charging power from the battery. RES. The control panel designed should also have protection components to maintain the reliability and lifetime of the hardware in it. Charge controllers, inverters, and microcontrollers should have their protection and power supply components to be free from the system they control. The test equipment used depends on the amount of data to be analyzed and the extent to which the installed equipment is to be tested. The final system of this research is the Uninterruptable Power System (UPS) because there are four sources of electrical energy, namely PLTS, PLTB, PLN, and generator set backup resources. This research is designed if one of the PLTS and PLTB power sources has a voltage of more than 11 VDC then the system will prioritize using the output of that power source by draining it to the battery and 
converting the DC power source to AC. However, if both PLTS and PLTB do not have enough voltage, which is more than $11 \mathrm{VDC}$, the system will use AC power sources either from PLN or generator sets. This system with an uninterrupted output power source is called a UPS. This system also uses on and off IoTbased controlling switching.

\subsection{Device Simulation}

After the design stage is complete, a simulation of the tool is carried out where at this stage, the system will be run. Switching system on and off controlling based on IoT Monitoring as monitoring the output of solar panels when one of the output values of voltage and current generated by PLTS, PLTB, PLN, and Generator is sufficient for the load, the other switches become Off, but when the output value of voltage and current is insufficient then switch on generator became On. The flowchart of the switching on and off controlling work system based on IoT Monitoring can be seen in Fig. 8.

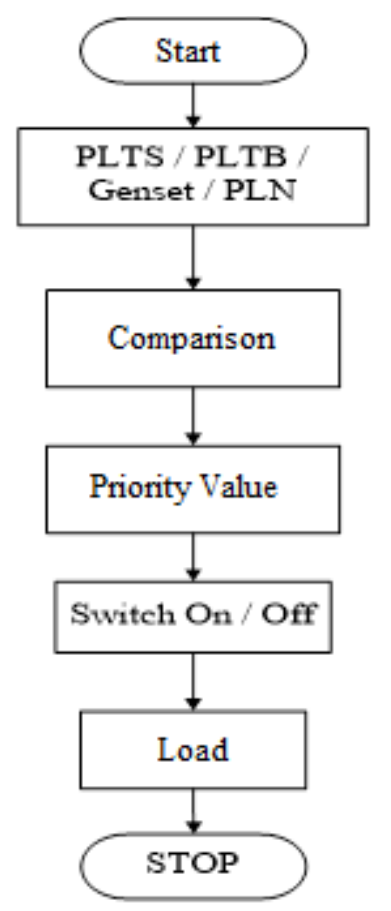

Figure 8 System Flow Chart

\section{RESULTS AND DISCUSSION}

\subsection{Effect of Voltage on Switch Displacement at the Battery Charging Source}

The performance test of solar panels and wind turbines when charging is given a set point at $13.3 \mathrm{~V}$. This test uses a simulation input which is like a renewable energy source. For example, solar panels are the top priority and wind turbines are the second priority for battery charging. If the two sources do not reach the set point, then the battery is not charging.

Table 1 Relay's Response to Input Voltage

\begin{tabular}{ccccc}
\hline No. & \multicolumn{2}{c}{ Input Voltage } & \multicolumn{2}{c}{ Relay Condition } \\
& A & B & A & B \\
\hline 1 & $18.8 \mathrm{~V}$ & $10 \mathrm{~V}$ & On & Off \\
2 & $18.9 \mathrm{~V}$ & $14 \mathrm{~V}$ & On & Off \\
3 & $11.3 \mathrm{~V}$ & $14.2 \mathrm{~V}$ & Off & On \\
4 & $11.3 \mathrm{~V}$ & $9.5 \mathrm{~V}$ & Off & Off \\
\hline
\end{tabular}

Table 1 shows the performance of the voltage sensor as the basic input for controlling the relay that the condition of Input A is the priority for charging the battery. When Input A has detected a voltage of more than $13.3 \mathrm{~V}$, the relay will activate the relay on input A. Moreover, if Input A is detected less than 
$13.3 \mathrm{~V}$ while input $\mathrm{B}$ is detected more than $13.3 \mathrm{~V}$, the relay will activate input $\mathrm{B}$ as an alternative source of charging the battery.

\subsection{Effect of Battery Set Point on ATS (Automatic Transfer Switch) at the Output}

The performance test of the effect of the battery set point on the ATS displacement at the output serves as an automatic disconnection test for the inverter output, which aims to prevent the battery from being dispersed in draining and maintaining battery health. This testing process takes time to get a battery with a voltage below the set point. Then it was found whether this tool was able to change from inverter input to PLN or Generator. The results of observations and measurements of the tool can be seen in Table 2.

Table 2 ATS Response to The Battery Set Point When Discharge

\begin{tabular}{cccc}
\hline \multirow{2}{*}{ Experiments } & \multicolumn{3}{c}{ Battery } \\
\cline { 2 - 4 } & Set Point & Voltage & Inverter \\
\hline 1 & $12 \mathrm{~V}$ & $12.9 \mathrm{~V}$ & $228 \mathrm{~V}$ \\
2 & $12 \mathrm{~V}$ & $12.6 \mathrm{~V}$ & $22 \mathrm{~V}$ \\
3 & $12 \mathrm{~V}$ & $12.5 \mathrm{~V}$ & $228 \mathrm{~V}$ \\
4 & $12 \mathrm{~V}$ & $12.7 \mathrm{~V}$ & $227 \mathrm{~V}$ \\
5 & $12 \mathrm{~V}$ & $12.3 \mathrm{~V}$ & $227 \mathrm{~V}$ \\
6 & $12 \mathrm{~V}$ & $12.2 \mathrm{~V}$ & $227 \mathrm{~V}$ \\
7 & $12 \mathrm{~V}$ & $12.0 \mathrm{~V}$ & $226 \mathrm{~V}$ \\
8 & $12 \mathrm{~V}$ & $11.9 \mathrm{~V}$ & $0 \mathrm{~V}$ \\
\hline
\end{tabular}

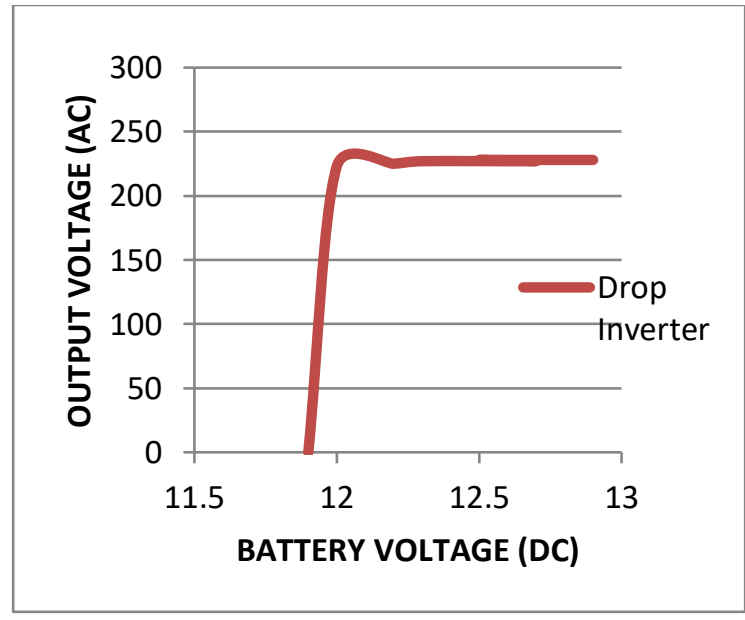

Figure 9 Graph of Inverter's Drop Point

Figure 9 and Table 2 results are obtained when the battery has reached the lowest voltage (Set Point), then the relay cut off the output on the inverter and made a power transition to PLN. When the voltage has reached 11.9 VDC, the voltage on the inverter can be seen changing to $0 \mathrm{VAC}$.

Table 3 ATS Response to The Battery Set Point When Charging

\begin{tabular}{cccc}
\hline \multirow{2}{*}{ Experiments } & \multicolumn{3}{c}{ Battery } \\
\cline { 2 - 4 } & Set Point & Voltage & Inverter \\
\hline 1 & $13 \mathrm{~V}$ & $11.7 \mathrm{~V}$ & $0 \mathrm{~V}$ \\
2 & $13 \mathrm{~V}$ & $11.8 \mathrm{~V}$ & $0 \mathrm{~V}$ \\
3 & $13 \mathrm{~V}$ & $11.9 \mathrm{~V}$ & $0 \mathrm{~V}$ \\
4 & $13 \mathrm{~V}$ & $12 \mathrm{~V}$ & $0 \mathrm{~V}$ \\
5 & $13 \mathrm{~V}$ & $12.5 \mathrm{~V}$ & $0 \mathrm{~V}$ \\
6 & $13 \mathrm{~V}$ & $12.7 \mathrm{~V}$ & $0 \mathrm{~V}$ \\
7 & $13 \mathrm{~V}$ & $12.8 \mathrm{~V}$ & $0 \mathrm{~V}$ \\
8 & $13 \mathrm{~V}$ & 13 & $229 \mathrm{~V}$ \\
\hline
\end{tabular}




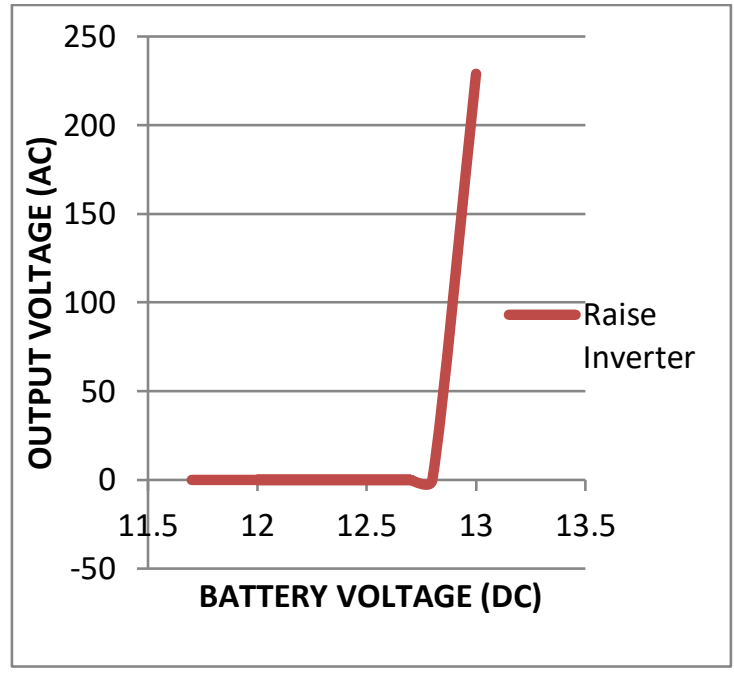

Figure 10 Graph of Inverter's Raise Point

Based on Table 3 and Fig. 10 above, the results obtained when the battery has reached the maximum voltage (Set Point), then the relay will reconnect the output to the inverter and will transition the power back to the inverter. When the voltage has reached $13 \mathrm{VDC}$, the voltage on the inverter can be seen to change to 229 VAC.

\subsection{Effect of Voltage on ATS (Automatic Transfer Switch) at the Output}

Voltage performance test on ATS displacement so that the output power is obtained as a trigger for output displacement. This testing process takes data using a power supply as a source of solar panels and wind turbines. The purpose of testing data collection with a power supply is to analyze the performance of the output displacement. The results of observing the performance of switching switches at the output can be seen in the following table.

Table 4 ATS Response to the Output

\begin{tabular}{cclcccc}
\hline \multirow{2}{*}{ No. } & \multicolumn{2}{c}{ PLN } & \multicolumn{3}{c}{ Condition } \\
\cline { 2 - 6 } & Inverter & Voltage & Generator & Inverter & PLN & Generator \\
\hline 1 & $0 \mathrm{~V}$ & $0 \mathrm{~V}$ & $0 \mathrm{~V}$ & OFF & OFF & OFF \\
2 & $0 \mathrm{~V}$ & $0 \mathrm{~V}$ & $225 \mathrm{~V}$ & OFF & OFF & ON \\
3 & $0 \mathrm{~V}$ & $224 \mathrm{~V}$ & $0 \mathrm{~V}$ & OFF & ON & OFF \\
4 & $0 \mathrm{~V}$ & $224 \mathrm{~V}$ & $226 \mathrm{~V}$ & OFF & ON & OFF \\
5 & $220 \mathrm{~V}$ & $0 \mathrm{~V}$ & $0 \mathrm{~V}$ & ON & OFF & OFF \\
6 & $220 \mathrm{~V}$ & $0 \mathrm{~V}$ & $226 \mathrm{~V}$ & ON & OFF & OFF \\
7 & $220 \mathrm{~V}$ & $224 \mathrm{~V}$ & $0 \mathrm{~V}$ & ON & OFF & OFF \\
8 & $220 \mathrm{~V}$ & $224 \mathrm{~V}$ & $226 \mathrm{~V}$ & ON & OFF & OFF \\
\hline
\end{tabular}

Performance Test of the Effect of Voltage on this experiment aims to prove the output priority scale between inverters, PLN electricity, and generators. It can be seen from the table that the output of the inverter is the main priority in the mains voltage source in this experiment. ATS (Automatic Transfer Switch) at the Output connection from each source will enter the ATS module automatically change the direction of electrical control to priority mode. In this experiment, the main priority is the inverter source, the second is PLN electricity, and the last is the generator. 


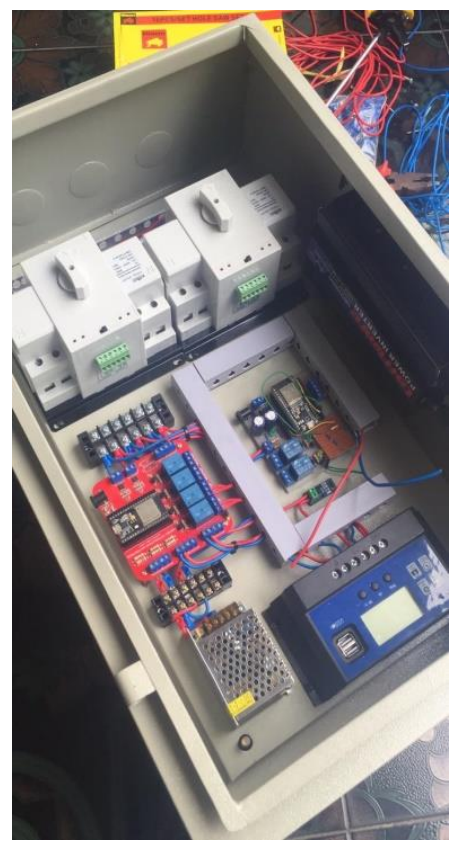

Figure 11 Device System

From the first experiment, the position of the voltage at the three outputs does not exceed the output in the OFF state. In the second experiment, the voltage position on the generator is $225 \mathrm{~V}$ AC while the other two outputs are not limited so that the generator becomes a source of voltage. In the third experiment, the voltage at the PLN electricity output so that the active power source comes from PLN electricity. Then in the fourth experiment, it was seen that the PLN and Generator voltages were detected because the second priority was PLN electricity, then PLN electricity was the priority of the power source. Furthermore, in the fifth experiment, the inverter detects a voltage of $220 \mathrm{~V}$. In contrast, the electricity from PLN and generators is not detected, then the inverter must prioritize the activation of the power source. The Inverter and Generator experiment detected that it emitted voltage and the power source still came from the Inverter. Furthermore, it was found that if the electricity from the Inverter is on and the Generator is on simultaneously, then the Inverter becomes the priority of the power source. Finally, in the eighth experiment, all outputs read the voltage, then again, the inverter will supply electricity to the socket.

Furthermore, the test proved to be successful and can be applied following the specified specifications and conditions. Therefore, this tool can control the input and output of electrical voltage sources, which can be a solution for priority needs in electricity development, ultimately combining renewable and conventional energy.

\section{CONCLUSION}

The Internet of Things-Based Hybrid Electric Energy Supply Automatic Control System is an option for controlling voltage in and out that combines renewable energy sources, PLN Electricity and Generators. This tool has three voltage sensors that function as regulators in controlling the system. In testing the Performance of the Effect of Voltage on Switch Displacement at the Battery Charging Source, it can be concluded that the tool is proven to perform performance according to the desired program. In testing the Effect of Voltage on ATS (Automatic Transfer Switch) at the output, eight possibilities can occur between the three outputs. Therefore, it can be concluded based on the table that this tool is able to control the output by considering the VAC voltage rate that will be controlled automatically according to the priority level which in this experiment the inverter output as the main priority, PLN electricity as the second priority and the last generator as the third priority.

\section{ACKNOWLEDGEMENTS} research.

The authors wish to give profound gratitude to Politeknik Negeri Sriwijaya has facilitated this 


\section{REFERENCES}

[1] Boedoyo, M. S., 2012, Potensi dan Peranan PLTS sebagai Energi Alternatif Masa Depan di Indonesia, Jurnal Sains dan Teknologi Indonesia Vol. 14, No. 2, 146-152 .

[2] Idzani Muttaqin., 2016, Analisa Rancangan Sel Surya dengan Kapasitas 50 Watt untuk Penerangan Parkiran UNISKA, Jurnal Teknik Mesin UNISKA Vol.1 No.2.

[3] Julisman, A., Sara, I. D., \& Siregar, R. h., 2017, Prototipe Pemanfaatan Panel Surya sebagai Sumber Energi pada Sistem Otomasi Atap Stadion Bola, KITEKTRO: Jurnal Online Teknik Elektro, Vol.2 No.1. 35-42.

[4] Ovi Irawan, Yohandri Bow, RD Kusumanto, 2021, Simulation and Peformance Test giromill Type Wind Turbine, International Journal of Research in Vocational Studies (IJRVOCAS), 2.

[5] Soeripno, M., \& Ibrahim, M., 2009, Analisa Potensi Energi Angin dan Estimasi Energi Output Turbin Angin di Lebak Banten, Jurnal Teknologi Dirgantara, Vol.7 No.1 , 51-59.

[6] Susanto, E., 2013, Automatic Transfer Switch, Jurnal Teknik Elektro, 18-21.

[7] R. Ploetz, R. Rusdianasari, E. Eviliana, 'Renewable Energy: Advantages and Disadvantages," Proceeding Forum in Research, Science, and Technology (FIRST), 2016.Kurniawan A, Taqwa A, Bow Y.2019. PLC Application as an Automatic Transfer Switch for on-grid PV System; Case Study Jakabaring Solar Power Plant Palembang J. Phys.: Conf. Ser. 1167012026

[8] R. B. Yuliandi, T. Dewi, and Rusdianasari, "Comparison of Blade Dimension Design of a Vertical Wind Turbine Applied in Low Wind Speed," In proceeding of E3S Web of Conferences EDP Sciences, Vol. 68, p. $01001,2018$.

[9] IRENA, Renewable Energy Prospects: Indonesia, a REmap analysis, International Renewable Energy Agency (IRENA), Abu Dhabi, 2017, www.irena.org/remap.

[10] Mirdiansyah, A. Taqwa, Y. Bow. Monitoring Depth of Discharge of a Valve Regulated Lead Acid Battery in a Standalone PV System. Proceedings of the 4th Forum in Research, Science, and Technology (FIRST-T1-T2-2020), 2021

[11] H.A. Harahap, T. Dewi, and Rusdianasari, "Automatic Cooling System for Efficiency and Output Enhancement of a PV System Application in Palembang, Indonesia," in 2nd Forum in Research, Science, and Technology, IOP Conf. Series: Journal of Physics: Conf. Series 1167 012027, 2019. doi:10.1088/1742-6596/1167/1/012027.

[12] B. Junianto, T. Dewi, and C. R. Sitompul,"Development and Feasibility Analysis of Floating Solar Panel Application in Palembang, South Sumatra Journal of Physics: Conf. Series 3nd Forum in Research, Science, and Technology Palembang, Indonesia, 2020.

[13] Y Bow, T Dewi, A Taqwa, Rusdianasari, Zulkarnain, Power Transistor 2N3055 as a Solar Cell Device, International Conference on Electrical Engineering and Computer Science (ICECOS), IEEE, 2018

[14] A. A. Sasmanto, T. Dewi, and Rusdianasari, "Eligibility Study on Floating Solar Panel Installation over Brackish Water in Sungsang, South Sumatra," EMITTER International Journal of Engineering Technology, Vol. 8, No. 1, 2020.

[15] K. Junaedi, T. Dewi, and M. S. Yusi, "The Potential Overview of PV System Installation at the Quarry Open Pit Mine PT. Bukit Asam, Tbk Tanjung Enim," Kinetik: Game Technology, Information System, Computer Network, Computing, Electronics, and Control, Vol. 6, No. 1, pp. 41-50, 2021. https://doi.org/10.22219/kinetik.v6i1.1148.

[16] Sarwono, T. Dewi, and RD Kusumanto, "Geographical Location Effects on PV Panel Output - Comparison Between Highland and Lowland Installation in South Sumatra, Indonesia," Technology Reports of Kansai University, Vol. 63, No. 02, pp. 7229-7243, 2021. ISSN: 04532198.

[17] A. Taqwa, T. Dewi, A. A. Sasmanto, Rusdianasari, and Y. Bow, "Feasibility Study and Design of IoT-based Monitoring for Remote PV System," Technology Reports of Kansai University, Vol. 63, No. 01, pp. 6933-6944, 2021. ISSN: 04532198.

[18] B. Hanafiah, A. Taqwa, RD Kusumanto, and T. Dewi, "Synchronization and Application of IoT for on Grid Hybrid PV-Wind System," In Proceeding of 2018 International Conference on Applied Science and Technology (iCAST) IEEE, p. 617-621, 2018.

[19] T. Dewi, P. Risma, Y. Oktarina, A. Taqwa, Rusdiansari, and H. Renaldi, "Experimental analysis on solar powered mobile robot as the prototype for environmentally friendly automated transportation," in Proceeding of Journal of Physics: Conference Series, International Conference on Applied Science and Technology (iCAST on Engineering Science) Bali, Indonesia, Vol. 1450, 2020.

[20] I. N. Zhafarina, T. Dewi, and Rusdianasari, “Analysis of Maximum Power Reduction Efficiency of Photovoltaic System at PT. Pertamina (Persero) RU III Plaju," VOLT: Jurnal Ilmiah Pendidikan Teknik Elektro, Vol. 3, No 1, pp.19-25, 2018.

[21] I. Arissetyadhi, T. Dewi, and RD Kusumanto, "Experimental Study on The Effect of Arches Setting on SemiFlexible Monocrystalline Solar Panels, " Kinetik: Game Technology, Information System, Computer Network, Computing, Electronics, and Control. KINETIK Vol. 5, No 2, pp. 111-118, 2020.

[22] P. P. Putra, T. Dewi, Rusdianasari, "MPPT Implementation for Solar-powered Watering System Performance Enhancement," Technology Reports of Kansai University, Vol. 63, No. 01, pp. 6919-6931, 2021. ISSN: 04532198.

[23] A. Edward, T. Dewi, and Rusdianasari, "The effectiveness of Solar Tracker Use on Solar Panels to The Output of The Generated Electricity Power IOP Conference Series," in Proceeding of Earth and Environmental Science, Vol. 347, No. 1, p. 012130, 2019.

[24] BRD. M. Hamdi, T. Dewi, and Rusdianasari, "Performance Comparison of 3 Kwp Solar Panels Between Fixed and Sun Tracking in Palembang-Indonesia," In Proceeding of IOP Conference Series: Earth and Environmental Science, Vol. 347, No. 1. p. 012131, 2019. 


\section{BIOGRAPHIES OF AUTHORS}

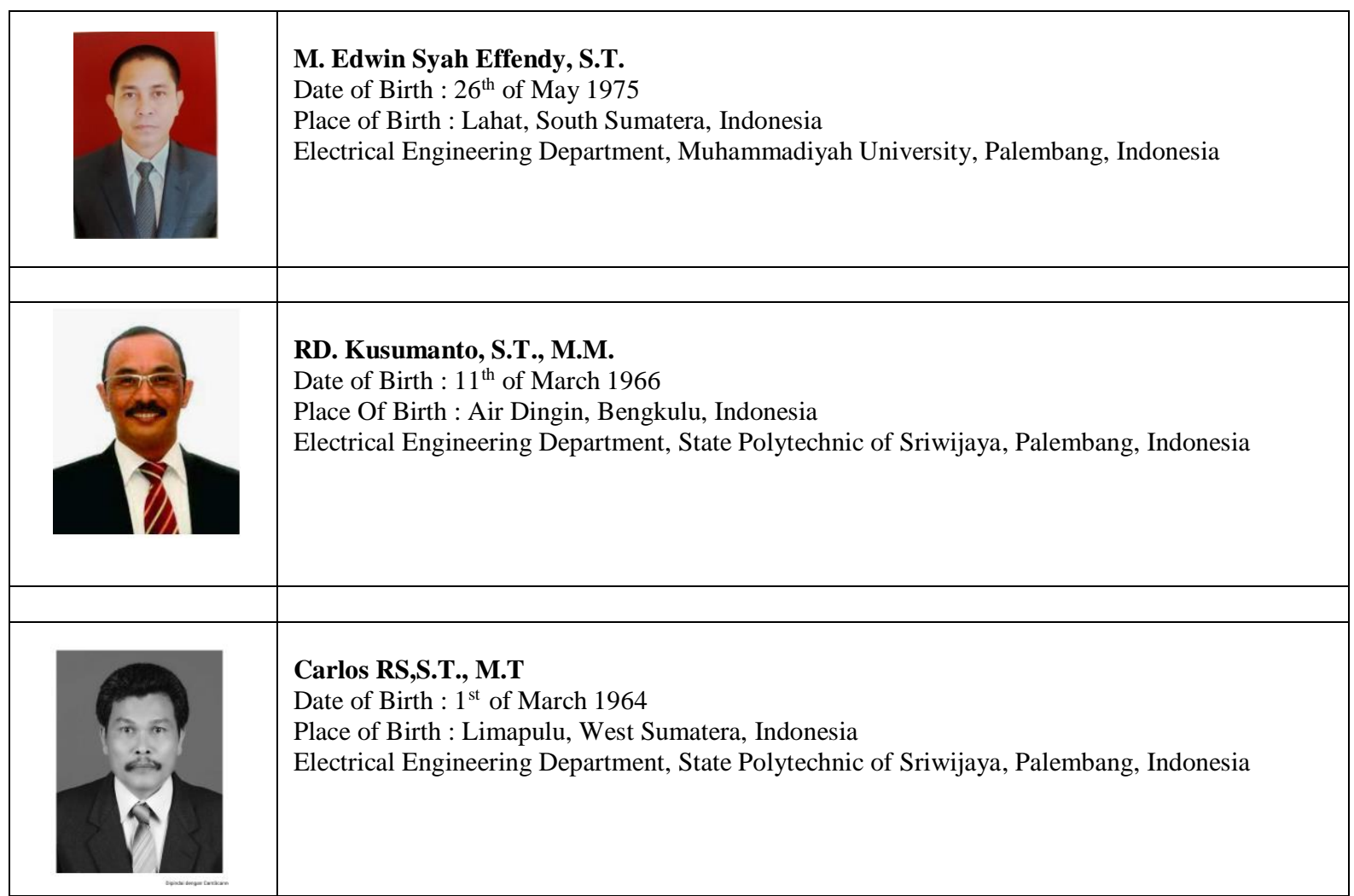

